\title{
Correction to: A novel miR-219-SMC4-JAK2/ Stat3 regulatory pathway in human hepatocellular carcinoma
}

Bo Zhou, Hongxu Chen, Dong Wei, Yi Kuang, Xiaobiao Zhao, Guangyao Li, Jun Xie and Ping Chen*

\section{Correction to: J Exp Clin Cancer Res 33, 55 (2014)}

https://doi.org/10.1186/1756-9966-33-55

Following publication of the original article [1], the authors identified minor errors in image-typesetting in Fig. 2; specifically, in Fig. 2D, the '97-h' panel (top left) has been replaced by the correct image.

The corrected figure is provided here. The corrections do not have any effect on the results or conclusions of the paper. The original article has been corrected.

Published online: 05 July 2021

\section{Reference}

1. Zhou B, Chen H, Wei D, et al. A novel miR-219-SMC4-JAK2/Stat3 regulatory pathway in human hepatocellular carcinoma. J Exp Clin Cancer Res. 2014;33: 55. https://doi.org/10.1186/1756-9966-33-55.

*Correspondence: chenpingsyd@126.com

Department of Hepatobiliary Surgery, Daping Hospital and Research Institute of Surgery, The Third Military Medical University, Chongqing, China

(c) The Author(s). 2021 Open Access This article is licensed under a Creative Commons Attribution 4.0 International License, which permits use, sharing, adaptation, distribution and reproduction in any medium or format, as long as you give appropriate credit to the original author(s) and the source, provide a link to the Creative Commons licence, and indicate if changes were made. The images or other third party material in this article are included in the article's Creative Commons licence, unless indicated otherwise in a credit line to the material. If material is not included in the article's Creative Commons licence and your intended use is not permitted by statutory regulation or exceeds the permitted use, you will need to obtain permission directly from the copyright holder. To view a copy of this licence, visit http://creativecommons.org/licenses/by/4.0/ The Creative Commons Public Domain Dedication waiver (http://creativecommons.org/publicdomain/zero/1.0/) applies to the data made available in this article, unless otherwise stated in a credit line to the data. 


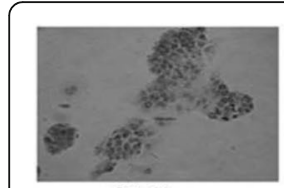

97-H

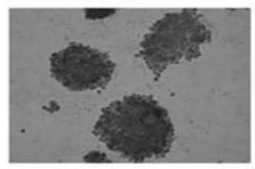

HepG2

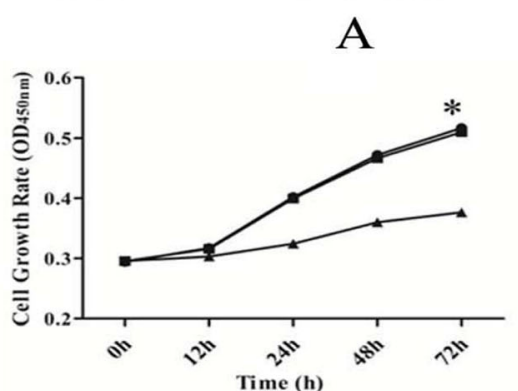

97-H-inhibit $\rightarrow$ 97-H

- 97-H-vector

× 97-H-inhibit

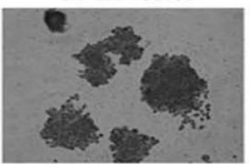

HepG2 -vector

HepG2 -inhibit
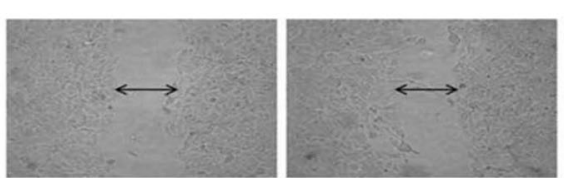

97-H-vector

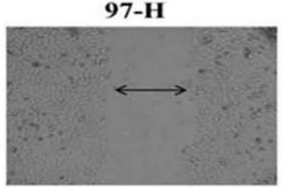

HepG2

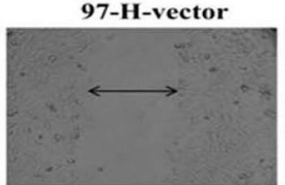

HepG2 -vector

C

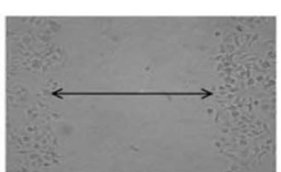

97-H-inhibit

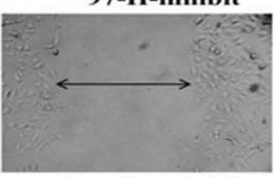

HepG2 -inhibit

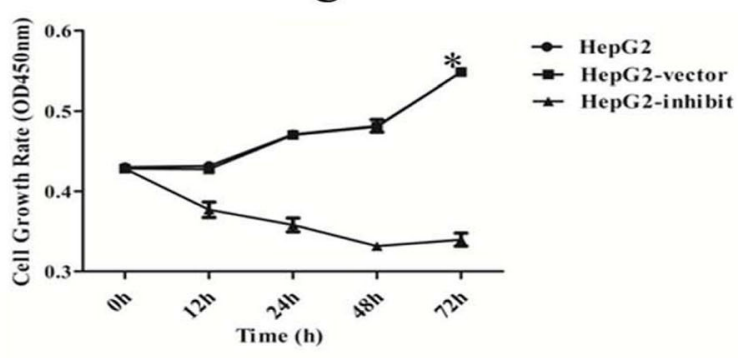

B

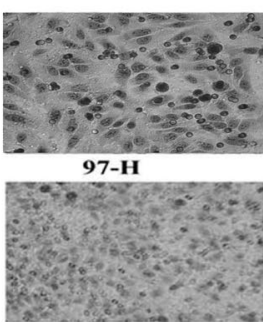

HepG2

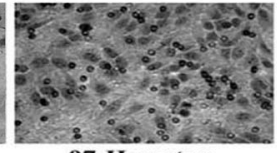

97-H-vector

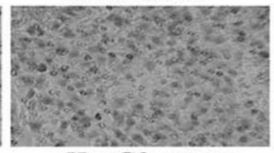

HepG2 -vector

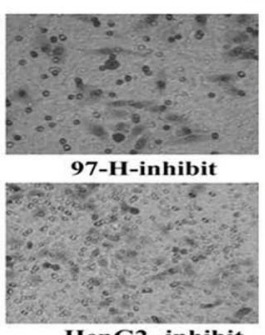

HepG2 -inhibit

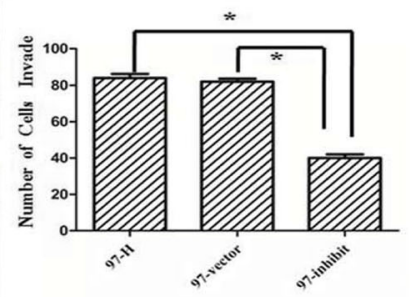

D

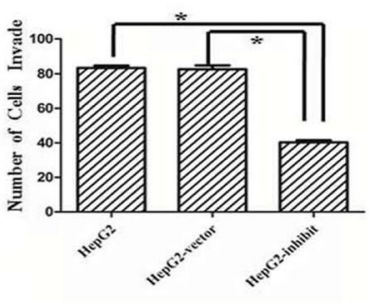

Fig. 2 SMC4 tumor-promoting effects $(\times 400)$. A Colony formation in soft agar after exposure to SMC4-homo-830. Representative images were taken at time $72 \mathrm{~h}$ after transfection. B Cell growth rates after exposure to SMC4-homo-830 as detected by WST-1 assay. C Wound-healing assays and cell motility after exposure to SMC4-homo-830. Representative images were taken at time $72 \mathrm{~h}$ after scratching. D SMC4-homo-830 decreased tumor cell invasion activity of $97-\mathrm{H}$ and HepG2 cells. $\left({ }^{*} p<0.05\right)$ 